\title{
Jurist-Diction
}

Volume 4 No. 6 November 2021

\section{Pertanggungjawaban Pidana Pelaku Tindak Pidana dalam Transaksi Jual Beli Pornografi di Media Internet}

\author{
Ghozi Naufal Qois \\ Ghozi.naufal.qois-2017@fh.unair.ac.id \\ Universitas Airlangga
}

How to cite:

Ghozi Naufal Qois

'Pertanggungjawaban Pidana Pelaku Tindak Pidana dalam Transaksi Jual Beli Pornografi di Media Internet' (2021) Vol. 4 No. 6 Jurist-Diction.

Histori artikel:

Submit 17 Mei 2021;

Diterima 15 Oktober 2021;

Diterbitkan 5 November 2021 .

DOI:

10.20473/jd.v4i6.31849

p-ISSN: 2721-8392

e-ISSN: 2655-8297

\section{Abstract}

Pornography has become a material for sale and purchase transactions. Pornographic transactions on the internet have many processes, so that there are many laws and regulations that can be applied. This creates legal uncertainty. The formulation of the problem in this research is the qualification of criminal acts related to pornography selling and buying transactions on the internet media and the accountability of criminals in selling and buying pornography on the internet media. The research method used is legal research through a conceptual approach and a statutory approach to assess existing legal problems. The results of this study show that the sale and purchase of pornography via the internet can be applied to the ITE and pornography laws. Then the responsibility depends on the evidence in the process of proving in court what the form of pornography is.

Keywords: Criminal Liability; Transactions; Buying and Selling; Pornography; Internet.

\begin{abstract}
Abstrak
Pornografi sudah menjadi bahan yang di transaksi jualbelikan. Transaksi pornografi di media internet memiliki banyak proses seperti penawaran, kesepakatan, penyerahan barang, dan pembayaran sehingga terdapat banyak peraturan perundang-undangan yang dapat diterapkan. Hal ini membuat ketidak pastian hukum. Rumusan masalah dalam penelitian ini adalah Kualifikasi tindak pidana terkait transaksi jualbeli pornografi di media internet dan pertanggungjawaban pelaku tindak pidana dalam transaksi jualbeli pornografi di media internet. Metode penelitian yang digunakan adalah legal research dengan melalui pendekatan konseptual dan pendekatan peraturan perundangundangan untuk mengkaji permasalahan hukum yang ada. Hasil dari penelitian tersebut diketahui bahwa transaksi jualbeli pornografi melalui internet dapat diterapkan Undang-Undang ITE dan Pornografi. kemudian pertanggungjawabannya tergantung dari pembuktian dalam proses pembuktian di dalam persidangan apakah bentuk dari pornografi tersebut.

Kata Kunci: Pertanggungjawaban Pidana; Transaksi; Jual Beli, Pornografi; Internet.
\end{abstract}




\section{Pendahuluan}

Perkembangan teknologi dan informasi terus berkembang secara pesat sesuai dengan Perkembangan zaman. Dengan perkembangan teknologi ini menjadikan kondisi dunia seakan-akan tidak memiliki batas negara, sehingga muncul pandangan bahwa dunia tidak terbagi lagi oleh ideologi tetapi teknologi. Oleh karena itu sekarang teknologi tidak dipisahkan dengan ilmu pengetahuan karena ilmu pengetahuan yang awalnya hanya berinteraksi dengan teknologi kini telah menjadi inovator didalam pengembangan teknologi canggih. Dengan ilmu pengatahuan dan teknologi yang semakin menyatu menyebaban kedua hal tersebut disebut IPTEK. ${ }^{1}$ Salah satu inovasi yang muncul pada era modern ini adalah adanya internet. Dengan kemajuan internet di era globalisasi ini telah merubah pola hidup di masyarakat seperti perubahan budaya, ekonomi, sosial, keamanan, hingga penegakan hukum. ${ }^{2}$

Adanya internet terhadap kehidupan sosial dan ekonomi masyarakat tidak selalu memberikan dampak positif, tetapi juga memunculkan dampak negatif, beberapa dampak megatif tersebut adalah munculnya kejahatan baru yaitu kejahatan dunia maya (cyber crime). ${ }^{3}$ Salah satu kejahatan dunia maya tersebut adalah kejahatan pornografi.

Kemajuan teknologi dengan adanya internet membuat penyebarluasan pornografi semakin mudah karena para pelaku tidak perlu lagi bertemu langsung dengan para peminat pornografi tersebut. Proses penawaran yang dapat dilakukan di internet seperti melalui blog, media sosial dan bentuk sarana lain yang ada di internet, kemudian proses penyebarluasan pornografi yang tidak lagi harus menggunakan sarana seperti VCD, DVD, majalah, dan bentuk lainnya, tetapi juga dapat berupa informasi atau dokumen elektornik yang dapat disebarluaskan langsung melalui media internet, serta jika terdapat transaksi yang harus

\footnotetext{
${ }^{1}$ Didik Endro P., Hukum Pidana Untaian Pemikiran (Airlangga University Press 2019).[49].

${ }^{2}$ Mutia Rahma Wardani dan Joko Priyono, 'Perlindungan Konsumen Dalam Transaksi Elektronik Melalui Instagram’ (2020) Vol. 13 NOTARIUS.[849].

${ }^{3}$ Kassandra Madya, 'Pertanggungjawaban Pidana Terhadap Pelaku Kejahatan Prostitusi Anak Melalui Transaksi Elektronik Berdasarkan Undang-Undang Nomor 19 Tahun 2016 Tentang Informasi Dan Transaksi Elektronik' (2019) Vol. 1 Jurnal of Law.[2].
} 
dipenuhi terlebih dahulu oleh peminat pornografi dapat langsung melakukan pembayaran melalui sistem pembayaran elektronik sehingga tidak perlu bertemu antara pelaku penyebarluasan pornografi dengan pihak yang berminat dengan pornografi tersebut. Dengan kemudahan tersebut membuat banyak sekali pihak yang menggunakan sarana tersebut untuk mencari kesempatan mendapatkan keuntungan dengan cara memperjualbelikan pornografi, Padahal pornografi dapat menyebabkan kejahatan-kejahatan lain seperti pemerkosaan, penindasan, bahkan hingga pembunuhan.

Di Indonesia Pada dasarnya telah ada peraturan perundang-undangan yang mengatur terkait pornografi di media internet dengan adanya Undang-Undang Republik Indonesia Nomor 19 Tahun 2016 Tentang Perubahan Atas UndangUndang Nomor 11 Tahun 2008 Tentang Informasi dan Transaksi Elektronik (selanjutnya disebut dengan UU ITE) yaitu pada Pasal 27 ayat (1) yang dimana mengatur terkait larangan yang berhubungan dengan penyebarluasan konten yang melanggar kesusilaan. Kemudian diatur pula di dalam Undang-Undang Undang-Undang Republik Indonesia Nomor 44 Tahun 2008 Tentang Pornografi (UU Pornografi) dalam Pasal 4 yang dimana mengatur perbuatan yang dilarang terhadap pornografi.

Dengan adanya media internet dan banyak bentuk kemesan dalam penyebarluasan pornografi seperti VCD, DVD, majalah, informasi atau dokumen elektronik, serta juga menjadikan pornografi sebagai objek yang di transaksikan untuk mencari keuntungan, membuat hukum juga harus menyesuaikan dengan kasus-kasus yang ada dilapangan agar tercipta kepastian hukum.

Hal ini menyebabkan penulis tertarik untuk mengakaji lebih dalam bagaimana bentuk pertanggungjawaban pidana bagi pelaku transaksi pornografi di media internet berdasarkan peraturan perundang-undangan yang telah ada. Oleh karena itu, berdasarkan latar belakang di atas maka akan dituangkan dalam bentuk penelitian dengan judul " Pertanggungjawaban Pidana Pelaku Tindak Pidana Dalam Transaksi Jual beli Pornografi Di Media Internet”. 


\section{Metode Penelitian}

Penelitian dilakukan secara normatif. Pendekatan terhadap masalah dilakukan melalui Pendekatan peraturan perundang-undangan (statute approach) dan Pendekatan konseptual (conceptual approach).

\section{Kualifikasi Tindak Pidana Terkait Transaksi Jual Beli Pornografi di Media Internet}

Para sarjana memberikan pendapatnya terkait definisi atau pengertian tentang pornografi yaitu: HB. Jassin ${ }^{4}$ menyatakan bahwa pomografi adalah setiap gambar atau tulisan yang ditulis atau digambar yang memiliki maksud dengan sengaja untuk merangsang seksual. Pornografi membuat fantasi yang melihat atau membaca menjadi terangsang dan syahwat berkobar-kobar di daerah kelaminan; Disini konsep pornografi yang digunakan adalah secara sempit yang dimana bentuk pornografi hanya dalam bentuk tulisan atau gambar, untuk zaman sekarang bentuk pornografi dapat lebih luas lagi seperti film. video, dan berbagai jenis bentuk informasi laiinya.

Neng Djubaedah ${ }^{5}$ memberikan definisi bahwa pomografi adalah visualisasi dan verbalisasi melalui media komunikasi, atau karya cipta manusia tentang perilaku atau perbuatan laki-laki dan atau perempuan yang erotis atau sensual, menunjukan keadaaan atau memberi kesan telanjang bulat yang menunjukan secara langsung alat-alat vital yang dapat merangsang nafus atau gairah seksual seperti tidak ditutup atau seakan-akan tidak ditutup bagian payudara atau pinggul dan sekitamya. Bentuk tindakan juga dapat seperti tarian, ciuman, bunyi atau desah yang memberi kesan persenggamaan atau percumbuan, gerakan masturbasi, homoseksual, lesbian, sodomi, oral seks, coffus interuptus. Tujuan atau akibat dari gambaran perbuatan tersebut mengakibatkan bangkitnya nafsu birahi.

Perbuatan yang merangsang bangkitnya nafsu birahi tersebut tidak saja antar pasangan yang berlainan jenis, baik antar muhrim atau antar bukan muhrim. Tetapi

${ }^{4}$ Tjipta Lesmana, Pornoqrafi Dalam Media Massa (Puspa Swara 1994).[109].

${ }^{5}$ Neng Djubaedah. Pornogafi dan Pornoaksi Ditinjau dari Hukum lslam (Prenada Media 2003).[254]. 
juga termasuk didalamnya perbuatan dengan sesame jenis. Kemudian juga termasuk hubunngan manusia dengan sesuatu hal yang tidak normal pada umumnya seperti antara manusia dengan binatang, antar binatang atau antara manusia hidup dengan manusia yang telah meninggal dunia atau bahkan dengan benda-banda mati seperti dildo dan alat seksualitas lainnya.

Selain perbuatan yang menimbulkan nafsu birahi, pornografi juga termasuk bagi orang yang melihatnya dan atau mendengamya dan atau menyentuhnya dapat muncul rasa menjijikkan dan atau memuakkan dan atau memalukan pada dirinya. Pada intinya adalah naiknya birahi seseorang dapat berbeda antara satu dengan yang lainnya, hal ini karena tergantung dengan kaidah-kaidah agama dan atau adatistiadat setempat

Pada dasarnya konsep pornografi pada suatu tempat berbeda dengan tempat yang lainnya. Perbedaan ini dikarenakan pandangan masyarakat tiap daerah yang berbeda dalam menilai suatu materi masuk dalam pornografi atau tidak. Perkembangan zaman juga mempengaruhi pandangan masyarakat terkait materi yang masuk dalam konsep pornografi.

Jika dilihat di dalam KUHP sendiri sebagai undang-undang umum hukum pidana, definisi pornografi sendiri tidak dijelaskan secara sprsifik. Tanpa adanya definisi pornografi di dalam KUHP ini menyebabkan banyak sekali kasus-kasus pornografi yang tidak dapat dijerat karena pasal-pasal yang terdapat didalam KUHP bersifat multitafsir atau tidak jelas. Oleh karena itu definisi pornografi diperjelas dengan dikeluarkannya Undang-Undang nomor 44 tahun 2008 tentang Pornografi yaitu:

\section{Pasal 1 angka 1}

Pornografi adalah gambar, sketsa, ilustrasi, foto, tulisan, suara, bunyi, gambar bergerak, animasi, kartun, percakapan, gerak tubuh, atau bentuk pesan lainnya melalui berbagai bentuk media komunikasi dan/atau pertunjukan di muka umum, yang memuat kecabulan atau eksploitasi seksual yang melanggar norma kesusilaan dalam masyarakat.

Jika dilihat konsep terkait pornografi pada dasarnya masih bersifat luas atau abstrak, tetapi terdapat esensi yang sama, yaitu sesuatu baik dalam bentuk tulisan, gambar atau berbagai bentuk media komunikasi, yang menggambarkan seksual atau sensualitas, dapat membuat siapa yang melihatnya membuat terangsang 
birahinya, hal tersebut bertentangan dengan moral yang ada dimasyrakat karena dapat merusak moral masyarakat serta merendahkan martabat manusia.

Jika dilihat disini maka moral masyarakat adalah tolak ukur yang sangat penting dalam mengukur bagaimana suatu bentuk informasi atau komusikasi apapun masuk dalam konsep pornografi. Pengaturan hukum pidana terkait pornografi ataupun penegak hukum terhadap kasus pornografi juga harus melihat pandangan -padangan yang ada dimasyarakat, baik dari segi moral, ideologi, budaya dan kepentingan-kepentingan Negara lainnya, karena hukum pidana sendiri adalah cerminan peradaban yang dimana ideologi, keadaan, kepentingan kepentingan suatu Negara mempengaruhi perkembangan hukum pidana di Negara tersebut.

Berkembangnya zaman perbuatan manusia tidak hanya dilakukan dengan perbuatan yang dilakukan didunia nyata, tetapi juga perbuatan yang dilakukan di dunia maya (cyber space). Begitu pula dengan perbuatan hukum yang dimana juga pada zaman sekarang ada yang dilakukan di dunia maya. salah satunya adalah transaksi elektronik.

Berdasarkan peraturan perundang-undangan yang berlaku di Indonesia yaitu pada Pasal 1 angka 2 Undang-Undang ITE yaitu "transaksi elektronik adalah perbuatan hukum yang dilakukan dengan menggunakan komputer, jaringan komputer, dan atau media elektronik lainnya". Dalam pengertian tersebut transaksi elektronik adalah suatu perbuatan hukum. Perbuatan hukum menurut Peter Mahmud Marzuki yang menyebutkan perbuatan hukum dengan istilah tindakan hukum bahwa "tindakan hukum adalah tindakan yang diatur oleh hukum",6 Tindakan yang mempunyai relevansi dengan hukum sehingga dalam tindakan tersebut mempunyai kaitan dengan adanya hak dan kewajiban subjek hukum, maka tindakan tersebut adalah Tindakan yang diatur oleh hukum. ${ }^{7}$ Perbuatan hukum juga memeliki relevansi dengan status subjek hukum karena perbuatan hukum dapat merubah atau menetapkan status subjek hukum. ${ }^{8}$

\footnotetext{
${ }^{6}$ Peter Mahmud, Pengantar Ilmu Hukum (kencana 2008).[210].

${ }^{7}$ ibid.

${ }^{8}$ ibid.
} 
Jika menurut R. Soeroso menyatakan bahwa perbuatan hukum adalah setiap perbuatan yang dilakukan dengan sengaja untuk menimbulkan hak dan kewajiban oleh subjek hukum (manusia atau badan hukum). perbuatan hukum baru terjadi apabila ada pernyataan kehendak akibat dari perbuatan ini yang diatur oleh hukum, karena akibat bisa dianggap sebagai kehendak dari yang melakukan hukum". 9

Jika dilihat dari pendapat para ahli di atas maka dapat disimpulkan bahwa perbuatan hukum adalah perbuatan yang memiliki relevansi dengan hukum, yang dilakukan oleh subjek hukum baik manusia atau badan hukum dengan sengaja, dengan adanya perbuatan tersebut mengakibatkan timbulnya akibat hukum seperti hak, kewajiban, atau status subjek hukum. Kemudian unsur transaksi elektronik selanjutnya adalah dengan menggunakan komputer, jaringan komputer, atau media elektronik lainnya. Maksud dari komputer jika dilihat dalam UndangUndang ITE, Pasal 1 angka 14 yaitu "Komputer adalah alat untuk memproses data elektronik, magnetik, optik, atau sistem yang melaksanakan fungsi logika, aritmatika, dan penyimpanan".

Jika dilihat dari pendapat para ahli seperti Robert H. Blissmer yang menyebutkan bahwa Komputer adalah suatu alat elektronik yang mampu melakukan beberapa tugas seperti menerima input, memproses input, menyimpan perintah-perintah dan menyediakan output dalam bentuk informasi. Kemudian pengertian Internet tidak dijelaskan didalam peraturan perundangundangan. Jika menurut pendapat para ahli yaitu Sibero menjelaskan terkait internet yaitu "Internet (Internconnected Network) adalah jaringan komputer yang menghubungkan antar jaringan secara global, internet dapat juga disebut jaringan dalam suatu jaringan yang luas". ${ }^{10}$ Jadi internet masuk dalam jaringan komputer. Jadi kesimpulan dari pengertian komputer di sini adalah alat elektronik yang dapat memproses informasi atau dokumen elektronik baik menyimpan data, memprosesnya, atau menyimpannya. salah satu bentuk dari jaringan komputer tersebut adalah internet.

\footnotetext{
${ }^{9}$ R. Soeroso. Pengantar Ilmu Hukum (Sinar Grafika 2011).[209].

${ }^{10}$ Alexander F. K. Sibero, Kitab Suci Web Programming (MediaKom 2011).[10].
} 
Menurut Pasal 17 ayat (1) Undang-Undang ITE Ruanglingkup dari transaksi adalah "Penyelenggaraan Transaksi Elektronik dapat dilakukan dalam lingkup publik ataupun privat". Pasal ini diperjelas dengan Peraturan Pemerintah Nomor 82 Tahun 2012 tentang Penyelenggaraan Sistem dan Transaksi Elektronik (selanjutnya disebut Peraturan Pemerintah tentang PSE) menjelaskan bahwa penyelenggaraan Transaksi Elektronik dalam lingkup privat meliputi Transaksi Elektronik: antar Pelaku Usaha; antara Pelaku Usaha dengan konsumen; antar pribadi; antar Instansi; dan antara Instansi dengan Pelaku Usaha sesuai dengan ketentuan peraturan perundang-undangan. ${ }^{11}$ Kemudian untuk ruang lingkup publik meliputi Penyelenggara Transaksi Elektonik yang dilakukan oleh instansi atau pihak lain yang menyelenggarakan layanan publik. ${ }^{12}$

Penyelenggaraan Transaksi Elektronik dalam lingkup publik atau privat yang menggunakan Sistem Elektronik untuk pelayanan publik dilaksanakan sesuai dengan ketentuan dalam Peraturan-perundang-undangan yang ada. ${ }^{13}$ Jika dilihat dari runglingkupnya maka transaksi elektonik disini memiliki minimal 2 pihak agar suatu perbuatan hukum dapat dikatakan suatu transaksi. Contoh dari para pihak tersebut adalah antar pelaku usaha,antar pribadi, atau bahkan dalam ruanglingkup publik seperti penyelenggara layanan publik.

Jadi disini yang dimaksud transaksi elektronik adalah segala perbuatan hukum yang dimana perbuatan hukum, dilakukan dengan menggunakan komputer, jaringan komputer, dan atau media elektronik lainnya, dilakukan oleh lebih dari satu pihak yang ruang lingkupnya sangat luas, baik itu secara privat ataupun secara publik sesuai dengan peraturan perundang-undangan yang berlaku. Kemudian Jual beli adalah perbuatan hukum yang dimana terdapat dua pihak yaitu penjual yang menawarkan barang dengan harga tertentu dan pembeli yang membutuhkan barang

\footnotetext{
${ }^{11}$ Peraturan Pemerintah Nomor 82 Tahun 2012 tentang Penyelenggaraan Sistem dan Transaksi Elektronik (Lembaran Negara Republik Indonesia Tahun 2012 Nomor 189).

${ }^{12}$ Peraturan Pemerintah Nomor 82 Tahun 2012 tentang Penyelenggaraan Sistem dan Transaksi Elektronik (Lembaran Negara Republik Indonesia Tahun 2012 Nomor 189).

${ }^{13}$ Peraturan Pemerintah Nomor 82 Tahun 2012 tentang Penyelenggaraan Sistem dan Transaksi Elektronik (Lembaran Negara Republik Indonesia Tahun 2012 Nomor 189).
} 
dan akan membayar sesuai dengan harga yang telah disepakati dengan penjual.

Jika dilihat dalam burgerkijk wetboek (selanjutnya disebut BW) terjemahan Sobekti dalam pasal 1457 mendefinisikan Jual beli adalah "suatu perjanjian dengan mana pihak yang satu mengikatkan dirinya untuk menyerahkan suatu kebendaan dan pihak yang lain untuk membayar harga yang telah diperjanjikan”.

Terjadinya jual beli adalah ketika telah ada kesepakatan diantara dua pihak yaitu antara penjual dan pembeli. Pada pasal 1458 BW menjelaskan bahwa jual beli dianggap telah terjadi antara kedua belah pihak seketika setelahnya orang-orang ini telah mencapai kesepakatan tentang kebendaan tersebut dan harganya, meskipun kebendaan tersebut belum diserahkan maupuun harganya belum dibayar. Hal ini sesuai dengan asas konsesualisme dalam perjanjian. ${ }^{14}$

Dalam perjanjian jual beli seorang penjual memiliki 2 kewajiban yang harus ia penuhi. Kewajiban tersebut berdasarkan Pasal 1473 BW yaitu

1. Menyerahkan barang;

2. Menanggung barang yang dijual.

Maksud dari penyerahan disini adalah terdapat pemindahan barang yang telah dijual berdasarkan perjanjian jual beli ke dalam kekuasaan dan kepemilikan pembeli. Dan maksud menanggung yang menjadi kewajiban si penjual adalah menjamin penguasaan benda yang dijual secara aman dan tentram serta menjamin bahwa tidak ada cacat barang yang tersembunyi. ${ }^{15}$ Berdasarkan pasal $1473 \mathrm{BW}$ bahwa penjual harus secara tegas untuk apa ia mengikatkan dirinya dan jika dalam perjanjian tersebut ada klausul yang tidak jelas maka akan menjadi kerugian untuk penjual itu sendiri. Dalam penyerahan pun juga tergantung dari jenis benda yang menjadi objek jual beli. Sebelum menjelaskan terkait penyerahan (levering) maka perlu diketahui terlebih dahulu jenis-jenis benda.

Jual beli adalah suatu bentuk perjanjian. Dinyatakan bahwa jual beli tersebut sah harus memenuhi syarat sahnya perjanjian, hal ini dapat dilihat didalam Pasal 1320 BW yang menyebutkan bahwa. Untuk sahnya suatu perjanjian diperlukan 4

\footnotetext{
${ }^{14}$ Simanjuntak, Hukum Perdata Indonesia (kencana 2015).[305].

${ }^{15}$ ibid.
} 
syarat yaitu:

1. Sepakat mereka yang mengikatkan dirinya;

2. Kecakapan untuk membuat perikatan;

3. Suatu hal tertentu;

4. Suatu sebab yang halal.

Maksud dari sebab yang halal adalah jika dilihat dari pasal 1337 BW bahwa suatu sebab sebab adalah terlarang jika dilarang oleh undang-undang atau apabila bertentang dengan kesusilaan atau ketertiban umum. Pada dasarnya transaksi jualbeli pornografi bukan perbuatan yang melanggar hukum jika transaksi tersebut sesuai dengan peraturan perundang-undangan yang berlaku ${ }^{16}$ dan juga harus dilakukan di tempat dan dengan cara khusus. ${ }^{17}$

Menurut Peraturan Pemerintah Republik Indonesia Nomor 5 Tahun 2014 Tentang Syarat Dan Tata Cara Perizinan Pembuatan, Penyebarluasan, Dan Penggunaan Produk Pornografi, mengatur terkait perizinan terhadap perbuatan yang berhubungan dengan pornografi. Dalam pasal 1 angka 5 Peraturan Pemerintah Republik Indonesia Nomor 5 Tahun 2014 Tentang Syarat Dan Tata Cara Perizinan Pembuatan, Penyebarluasan mengatur bahwa, Pasal 1 angka 5:

Izin yang diperbolehkan adalah untuk melakukan adalah pernyataan mengabulkan secara tertulis yang diberikan oleh pejabat yang berwenang untuk:

a. melakukan Pembuatan, Penyebarluasan, dan Penggunaan Produk Pornografi untuk tujuan dan kepentingan pendidikan;

b. melakukan Pembuatan, Penyebarluasan, dan Penggunaan Produk Pornografi untuk tujuan dan kepentingan pelayanan kesehatan; atau

c. melakukan Pembuatan, Penyebarluasan, dan Penggunaan Produk Pornografi yang harus dilakukan di tempat dan dengan cara khusus.

Dalam proses penyebarluasan pornografi memilik syarat yang harus dipenuhi. Untuk penyebarluasan produk pornografi dengan tujuan dan kepentingan pendidikan, paling sedikit harus memenuhi syarat yaitu disebarluaskan secara terbatas di lingkungan lembaga pendidikan, sesuai dengan jenjang pendidikan;

\footnotetext{
${ }^{16}$ Undang-Undang Republik Indonesia Nomor 44 tahun 2008 Tentang Pornografi (Lembaran Negara Republik Indonesia Tahun 2008 Nomor 181).

${ }^{17}$ Undang-Undang Republik Indonesia Nomor 44 tahun 2008 Tentang Pornografi (Lembaran Negara Republik Indonesia Tahun 2008 Nomor 181).
} 
sesuai dengan bidang ilmu dan/atau profesi. ${ }^{18}$ kemudian untuk penyebarluasan Produk Pornografi untuk tujuan dan kepentingan Pelayanan Kesehatan paling sedikit harus memenuhi syarat yaitu dilakukan di tempat atau lokasi tertentu dan/atau dapat diakses ke tempat tertentu yang terdeteksi dan dapat dipantau dengan akurat, untuk kepentingan penanggulangan bahaya kesehatan masyarakat dan/atau program pemerintah; untuk kepentingan kesehatan orang perseorangan, harus dilakukan oleh tenaga medis dan/atau tenaga keterapian fisik; dan diketahui oleh pimpinan lembaga pelayanan kesehatan jika disebarluaskan oleh Tenaga Kesehatan. ${ }^{19}$

Jadi jika suatu transaksi pornografi tidak mendapatkan izin dari pihak yang berwenang memberikan izin maka perbuatan tersebut adalah perbuatan melanggar hukum. Dengan demikian pada dasarnya jika seseorang telah melakukan jual beli pornografi yang dimana telah dilakukan telah terjadi kesepakatan untuk melakukan pengiriman barang yang berisi pornografi, baik dalam bentuk informasi elektronik ataupun dalam bentuk berwujud seperti gambar atau benda berwujud lainnya, serta telah ada pembayaran seseuai dengan harga yang telah ditentukan, maka telah terjadi jualbeli pornografi. Walaupun seakan-akan telah terjadi jualbeli, tetapi jualbeli tersebut adalah jualbeli yang tidak sah karena barang yang dijual adalah barang yang dilarang oleh undang-undang.

Jadi transaksi pornografi di media internet adalah perbuatan hukum yang dilakukan oleh para pihak baik seseorang atau badan hukum. Memiliki akibat hukum dan diatur oleh hukum, dimana perbuatan hukum dalam kasus ini adalah perbuatan jual beli yang terdapat beberapa proses seperti penawaran, kesepakatan, pembayaran, dan penyerahan barang, objek yang dijadikan dalam transaksi adalah pornografi, dilakukan di media internet yang merupakan jaringan komputer dan dilakukan tanpa izin dari pihak yang berwenang.

\footnotetext{
${ }^{18}$ Peraturan Pemerintah Republik Indonesia Nomor 5 Tahun 2014 Tentang Syarat Dan Tata Cara Perizinan Pembuatan, Penyebarluasan, Dan Penggunaan Produk Pornografi (Lembaran Negara Republik Indonesia Tahun 2014 Nomor 17).

${ }^{19}$ Peraturan Pemerintah Republik Indonesia Nomor 5 Tahun 2014 Tentang Syarat Dan Tata Cara Perizinan Pembuatan, Penyebarluasan, Dan Penggunaan Produk Pornografi (Lembaran Negara Republik Indonesia Tahun 2014 Nomor 17).
} 


\section{Pertanggungjawaban Pelaku Tindak Pidana dalam Transaksi Jual beli Pornografi di Media Internet}

Pada dasarnya telah dijelaskan sebelumnya bahwa dalam KUHP tidak menjelaskan secara khusus mengenai pornografi. Tetapi tindak pidana pornografi dimasukan kedalam buku II Bab XIV Tentang Kejahatan Terhadap Kesusilaan.

Menurut R. Soesilo ${ }^{20}$ menjelaskan bahwa "kesusilaan"dapat diartikan sebagai "kesopanan" yaitu perasaan malu yang berhubungan dengan nafsu kelamin. Pada penjelasan KUHP terjemahan R. Soesilo, pengertian kesusilaan disini masih kurang jelas sehingga masih sulit dipahami.

S. R. Sianturi ${ }^{21}$ menjelaskan pengertian kesusilaaan, sebagai berikut: "yang dimaksud kesusilaan adalah dalam arti yang bukan hanya menyangkut soal kebirahian atau seks saja. Akan tetapi mempunyai kebiasaan hidup yang pantas dan berahlak dalam suatu kelompok masyarakat (tertentu) yang sesuai dengan sifat masyarakat yang bersangkutan”. Berdasarkan pendapat S. R. Sianturi bahwa pengertian kesusilaan disini memiliki konsep yang lebih luas dibandingkan pendapat $\mathrm{R}$. soesilo karena tidak hanya menyangkut soal kebirahian atau seks saja, tetapi juga termasuk didalamnya perbuatan yang tidak pantas dalam kelompok masyarakat tertentu.

Jika ditarik kesimpulan dari pendapat R. soesilo dan S.R. Sianturi bahwa kesusilaan adalah sesuatu yang tidak hanya berhubungan dengan nafsu kelamin dan seksualitas. Tetapi juga perbuatan yang sesuai dengan sifat masyarakat dalam suatu masyarakat tertentu menilai perbuatan tersebut sebagai perbuatan yang tidak pantas dan tidak berakhlak. Jadi pada dasarnya KUHP memasukan pornografi ke dalam delik kesusilaan karena permasalah pornografi lebih dilihat dari sudut pandang persoalan moralitas. Oleh karena itu KUHP memasukan pornografi dalam bab delik kesusilaan sama seperti Wetboek van Strafrecht.yang dikelompokkan secara umum sebagai berikut: a. Tulisan, atau gambar, atau benda yang melanggar

\footnotetext{
${ }^{20}$ Soesilo, KUHP Serfa Komentar komentamya Lengkap Pasal demi Pasal (Politei 1995). [204].

${ }^{21}$ S.R. Sianturi. Asas-Asas Hukum Pidana di Indonesia dan Penerapannya. (Alumni Ahaem-Petehaem 1996).[26].
} 
kesusilaan (pasal 282-283 KUHP); b. Tulisan, atau gambar, atau benda yang dapat membangkitkan atau merangsang nafsu birahi ( Pasal-pasal 532-533 KUHP).

Berikut ketentuan tindak pidana pornografi yang diatur di dalam Pasal 282 -283 KUHP yaitu Pasal 282:

(1) Barangsiapa menyiarkan, mempertunjukkan atau menempelkan di muka umum tulisan, gambaran atau benda yang telah diketahui isinya melanggar kesusilaan, atau barang siapa dengan maksud untuk disiarkan, dipertunjukkan atau ditempelkan di muka umum, membikin tulisan, gambaran atau benda tersebut, memasukkannya ke dalam negeri, meneruskannya, mengeluarkannya dari negeri, atau memiliki persediaan, ataupun barang siapa secara terangterangan atau dengan mengedarkan surat tanpa diminta, menawarkannya atau menunjukkannya sebagai bisa diperoleh, diancam dengan pidana penjara paling lama satu tahun enam bulan atau pidana denda paling tinggi empat ribu lima ratus rupiah.

(2) Barangsiapa menyiarkan, mempertunjukkan atau menempelkan di muka umum tulisan, gambaran atau benda yang melanggar kesusilaan, ataupun barang siapa dengan maksud untuk disiarkan, dipertunjukkan atau ditempelkan di muka umum, membikin, memasukkan ke dalam negeri, meneruskan mengeluarkannya dari negeri, atau memiliki persediaan, ataupun barang siapa secara terang-terangan atau dengan mengedarkan surat tanpa diminta, menawarkan, atau menunjuk sebagai bisa diperoleh, diancam, jika ada alasan kuat baginya untuk menduga bahwa tulisan, gambazan atau benda itu me!anggar kesusilaan, dengan pidana paling lama sembilan bulan atau pidana denda paling banyak empat ribu lima ratus rupiah.

(3) Kalau yang bersalah melakukan kejahatan tersebut dalam ayat pertama sebagai pencarian atau kebiasaan, dapat dijatuhkan pidana penjara paling lama dua tahun delapan bulan atau pidana denda paling banyak tujuh puluh lima ribu rupiah.

Pasal 283

(1) Diancam dengan pidana penjara paling lama sembilan bulan atau pidana denda paling banyak sembilan ribu rupiah, barang siapa menawarkan, memberikan untuk terus maupun untuk sementara waktu, menyerahkan atau memperlihatkan tulisan, gambaran atau benda yang melanggar kesusilaan, maupun alat untuk mencegah atau menggugurkan kehamilan kepada seorang yang belum dewasa, dan yang diketahui atau sepatutnya harus diduga bahwa umumya belum tujuh belas tahun, jika isi tulisan, gambaran, benda atau alat itu telah diketahuinya.

(2) Diancam dengan pidana yang sama, barang siapa membacakan isi tulisan yang melanggar kesusilaan di muka oranng yang belum dewasa sebagaimana dimaksud dalam ayat yang lalu, jika isi tadi telah diketahuinya.

(3) Diancam dengan pidana penjara paling lama empat bulan atau pidana kurungan paling lama tiga bulan atau pidana denda paling banyak sembilan ribu rupiah, 
barang siapa menawarkan, memberikan untuk terus maupun untuk sementara waktu, menyerahkan atau memperlihatkan, tulisan, gambaran atau benda yang melanggar kesusilaan, maupun alat untuk mencegah atau menggugurkan kehamilan kepada seorang yang belum dewasa sebagaimana dimaksud dalam ayat pertama, jika ada alasan kuat baginya untuk menduga, bahwa tulisan, gambaran atau benda yang melanggar kesusilaan atau alat itu adalah alat untuk mencegah atau menggugurkan kehamilan.

Kedua pasal tersebut memiliki perbedaan pengaturan secara mendasar terkait pornografi yaitu dalam Pasal 282 KUHP mengatur terkait penyebaran pornografi. Penyebaran seperti mempertunjukan. Penyebaran di dalam negeri ataupun keluar negeri, ataupun mendapatkan bahan pornografi dari luar negeri. Sedangkan dalam Pasal 283 KUHP lebih spesifik untuk melindung anak-anak dibawah umur dari pihak yang tidak bertanggungjawab, yang menyerahkan atau memperlihatkan tulisan, gambaran atau benda yang melanggar kesusilaan, maupun alat untuk mencegah atau menggugurkan kehamilan. Tetapi kembali lagi bahwa di dalam KUHP tidak menjelaskan secara spesifik apa yang dimaksud melanggar kesusilaan. Dengan demikian diperlukan tinjauan dari pendapat para ahli terkait apa yang dimaksud melanggar kesusilaan jika ingin menerapkan pasal tersebut.

Jika melihat di dalam KUHP yang dimana tidak ada definisi secara spesifik apa itu pornografi dan tindak pidana pornografi dimasukan kedalam delik kesusilaan, padahal pengertian kesusilaan sendiri memiliki pengertian yang sangat luas. Jadi unsur tindak pidana pornografi diatur secara umum di dalam KUHP yang dimana tindak pidana pornografi dimasukan kedalam buku II Bab XIV Tentang Kejahatan Terhadap Kesusilaan. Oleh karena itu tindak pidana pornografi diperjelas dengan dikeluarkannya Undang-Undang Nomor 44 Tahun 2008 tentang Pornografi

Dalam undang-undang ini mengatur lebih spesifik terhadap pornografi jika dibanding dengan undang-undang yang lain. Dalam Undang-Undang Pornografi ini memberikan definisi pornografi yang jelas di dalam Pasal 1 angka 1. Dalam kontek transaksaksi pornografi juga diatur lebih spesifik didalam undang-undang ini.

Perbuatan yang dilarang terkait trnsaksi pornografi diatur di dalam Pasal 4 undang-undang pornografi yang berbunyi: 
(1) Setiap orang dilarang memproduksi, membuat, memperbanyak, menggandakan, menyebarluaskan, menyiarkan, mengimpor, mengekspor, menawarkan, memperjualbelikan, menyewakan, atau menyediakan pornografi yang secara eksplisit memuat:

a. persenggamaan, termasuk persenggamaan yang menyimpang;

b. kekerasan seksual;

c. masturbasi atau onani;

d. ketelanjangan atau tampilan yang mengesankan ketelanjangan;

e. alat kelamin; atau

f. pornografi anak.

(2) Setiap orang dilarang menyediakan jasa pornografi yang:

a. menyajikan secara eksplisit ketelanjangan atau tampilan yang mengesankan ketelanjangan;

b. menyajikan secara eksplisit alat kelamin;

c. mengeksploitasi atau memamerkan aktivitas seksual; atau

d. menawarkan atau mengiklankan, baik langsung maupun tidak langsung layanan seksual.

Dalam Pasal 4 ini tidak hanya secara spesifik melarang transaksi pornografi seperti memperjualbelikan, menyewakan, mengekspor atau mengimpor pornografi, tetapi juga perbuatan lain yang dilarang terhadap konten yang mengandung unsur pornografi seperti menggandakan, memperbanyak, dan perbuatan yang lainnya. perbuatan meminjamkan atau mengunduh pornografi sebagaimana dimaksud dalam Pasal 4 ayat (1) juga dilarang bagi Setiap orang. ${ }^{22}$ Perlu diketahui pula bahwa terdapat pengecualian yaitu jika membuat pornografi untuk dirinya sendiri dan kepentingan sendiri maka tidak termasukdalam konsep "membuat" dalam Pasal 4 ayat (1) Undang-Undang Pornografi. ${ }^{23}$

Jadi pengaturan terkait tindak pidana pornografi diatur lebih spesifik di dalam Undang-Undang pornografi yang dimana pornografi didefinisikan lebih jelas dan tindak pidana terkait pornografi diatur lebih khusus di dalam Undang-Undang ini. Serta dalam Undang-Undang ini mengatur terkait transaksi pornografi yang tidak melawan hukum.

Terkait transaksi pornografi di media internet yang melanggar hukum terdapat Undang-Undang ITE . Dalam undang-undang ini yang mengatur terkait pornografi

\footnotetext{
${ }^{22}$ Undang-Undang Republik Indonesia Nomor 44 tahun 2008 Tentang Pornografi (Lembaran Negara Republik Indonesia Tahun 2008 Nomor 181).

${ }^{23}$ Undang-Undang Republik Indonesia Nomor 44 tahun 2008 Tentang Pornografi (Lembaran Negara Republik Indonesia Tahun 2008 Nomor 181).
} 
di atur dalam BAB VII tentang Perbuatan Yang Dilarang dalam Pasal 27 ayat 1 Undang-Undang ITE. Konsep pornografi disini dimasukkan kedalam informasi atau dokumen elektronik yang melanggar kesusilaan. Bunyi dari pasal tersebut adalah Pasal 27 ayat (1)

Setiap Orang dengan sengaja dan tanpa hak mendistribusikan dan/atau mentransmisikan dan/atau membuat dapat diaksesnya Informasi Elektronik dan/ atau Dokumen Elektronik yang memiliki muatan yang melanggar kesusilaan.

Dalam pasal ini jika dilihat dari perumusan pasal atau formulasi penyusunan, maka tindak pidana ini masuk kedalam tindak pidana khusus dalam ruang lingkup ITE. Perbuatan mendistribusikan, mentransmisikan, atau membuat dapat diaksesnya informasi elektronik atau dokumen elektronik merupakan perbuatan yang melanggar hukum jika terdapatmuatan yang melanggar kesusilaan di masyarakat. Jadi Jika dilihat dari sifat melawan hukum atau kepentingan yang hendak dilindungi maka perbuatan tersebut dapat dikelompokkan ke dalam tindak pidana kesusilaan. ${ }^{24}$

Jadi jika dilihat dalam pasal ini bahwa pidana pokoknya adalah kesusilaan, kemudian sarananya adalah melalui sistem/ jaringan ITE. Oleh karena itu Pasal 27 ayat (1) Undang_Undang ITE ini adalah lex spesialis dari bab XIV KUHP. Konsep ini dipertegas dalam Putusan Mahkamah konstitusi Nomor 50/PUUVI/2008 yang menjelaskan terkait kedudukan hukum dalam pasal 27 ayat (3) Undang-Undang ITE.

Dalam putusan tersebut menjelaskan bahwa Kedudukan norma hukum pidana dalam pasal 27 ayat (3) Undang-Undang ITE terkait tindak pidana penghinaan dan pencemaran nama baik tidak mengatur norma hukum pidana baru, melainkan hanya mempertegas berlakunya norma hukum pidana penghinaan dalam KUHP. Penegasan yang diatur di dalam undang-undang baru ini karena ada unsur tambahan yang khusus yaitu perkembangan hukum di bidang elektronik/siber. Penafsiran norma yang dimuat Pasal 27 ayat (3) Undang-Undang ITE mengenai penghinaan

\footnotetext{
${ }^{24}$ Adami Chazawi dan Ardi Ferdian, Tindak pidana informasi \& transaksi elektonik penyerangan terhadap kepentingan hukum pemanfaatan teknologi informasi dan transaksi elektronik (Media nusa creative 2015).[10].
} 
dan/atau pencemaran nama baik tidak bisa dilepaskan dari norma hukum pidana yang dimuat dalam Bab XVI tentang Penghinaan yaitu dalam Pasal 310 dan Pasal 311 KUHP. Jadi, norma di dalam KUHP merupakan hukum pokok/dasar (genus delict), sedangkan norma hukum dalam Pasal 27 ayat (3) Undang-Undang ITE merupakan ketentuan pemberlakuan secara khusus dari KUHP.

Jika diambil analisis dalam putusan ini maka pada dasarnya Undang-Undang ITE adalah kententuan khusus dari KUHP karena adanya perkembangan hukum dibidang elektroni/ siber. Jadi Undang-Undang ITE terkait pasal 27 ayat (1) yang mengatur terkait muatan yang melanggar kesusilaan tidak bisa lepas dari kesusilaan yang diatur didalam KUHP.

Objek dari Pasal 27 ayat (1) Undang-Undang ITE ini adalah informasi atau dokumen elektonik yang muatannya melanggar kesusilaan. Definsi informasi dan dokumen elektornik terdapat pada Pasal 1 angka 1 dan angka 4 Undang-Undang ITE yaitu:

\section{Pasal 1}

Angka 1.

Informasi Elektronik adalah satu atau sekumpulan data elektronik, termasuk tetapi tidak terbatas pada tulisan, suara, gambar, peta, rancangan, foto, electronic data interchange (EDI), surat elektronik (electronic mail), telegram, teleks, telecopy atau sejenisnya, huruf, tanda, angka, Kode Akses, simbol, atau perforasi yang telah diolah yang memiliki arti atau dapat dipahami oleh orang yang mampu memahaminya

Angka 4.

Dokumen Elektronik adalah setiap Informasi Elektronik yang dibuat, diteruskan, dikirimkan, diterima, atau disimpan dalam bentuk analog, digital, elektromagnetik, optikal, atau sejenisnya, yang dapat dilihat, ditampilkan, dan/ atau didengar melalui Komputer atau Sistem Elektronik, termasuk tetapi tidak terbatas pada tulisan, suara, gambar, peta, rancangan, foto atau sejenisnya, huruf, tanda, angka, Kode Akses, simbol atau perforasi yang memiliki makna atau arti atau dapat dipahami oleh orang yang mampu memahaminya

Kemudian perumusan dalam Pasal 27 ayat (1) Undang Undang ITE ini terdapat 3 perbuatan yang dilarang, meskipun tiga perbuatan tersebut dipisahkan oleh frasa "dan/atau", tetapi perbuatan-perbuatan tersebut adalah perbuatan yang berbeda. 
2358 Ghozi Naufal: Pertanggungjawaban Pidana Pelaku...

Di dalam Penjelasan Undang-undang Undang-Undang ITE, menjelaskan bahwa Yang dimaksud dengan "mendistribusikan" adalah mengirimkan dan/atau menyebarkan Informasi Elektronik dan/atau Dokumen Elektronik kepada banyak Orang atau berbagai pihak melalui Sistem Elektronik. Jika dilihat dari selesainya tindak pidananya maka tindak pidana dengan cara mendistribusikan informasi dan. atau dokumen elektronik yang isinya melanggar kesusilaan adalah tindak pidana yang bersifat formil karena tidak perlu dibuktikan bahwa yang menerima informasi/ dokumen elektronik itu telah melihat secara virtual informasi/dokumen elektornik. Tapi karena pembuktian dalam kasus ITE sangatlah susah untuk diketahui/ dideteksi sebelum ada orang yang melihat atay mengakses informasi/ dokumen elektronik tersebut. Oleh karena itu "keadaan"sseorang telah mengetahui informasi tersebut melalui komputernya jangan sampai diabaikan dalam pertimbangan. Yang dimaksud dengan "membuat dapat diakses" adalah semua perbuatan lain selain mendistribusikan dan mentransmisikan melalui Sistem Elektronik yang menyebabkan Informasi Elektronik dan/atau Dokumen Elektronik dapat diketahui pihak lain atau publik.

Berbeda dengan perbuatan lain yang lebih konkret, perbuatan membuat dapat diakses disini dibuat lebih abstrak karena maksud dari pembuat undang-undang adalah untuk menampung perbuatan yang bukan termasuk dari mendistribusikan atau mentransmisikan dapat dijerat dengan pasal ini. Jika dilihat dari wujud perbuatannya, membuat dapat diakses berbeda dengan perbuatan mendistribusikan atau mentransmisikan yang bersifat formil karena dalam tindakan membuat dapat diaksesnya haruslah benar-benar terbukti bahwa informasi tersebut harus dapat diakses oleh umum sehingga perbuatan membuat dapat diaksesnya informasi/ dokumen elektronik yang melanggar keasusilaan bersifat tindak pidana materiil.

Jika dikaitkan antara konsep transaksi elektronik yang merupakan perbuatan hukum yang dilakukan dengan menggunakan media elektronik dan perbuatan yang diatur didalam pasal 27 ayat (1) Undang-Undang ITE terkait penyebarluasan informasi atau dokumen elektronik yang bermuatan melanggar kesusilaan, maka perbuatan mendistribusikan dan/atau mentransmisikan dan/atau membuat dapat 
diaksesnya Informasi Elektronik informasi atau dokumen elektronik yang bermuatan melanggar kesusilaan masuk didalam konsep transaksi elektonik karena perbuatan tersebut adalah perbuatan hukum yang dilakukan menggunakan media elektronik.

Jika dikaitkan dengan transaksi jualbeli pornografi di media internet yang dimana terdapat beberapa proses seperti penawaran, pembayaran, penyebarluasan pornografi itu sendiri maka Undang-Undang ITE hanya dapat digunakan jika dalam proses tersebut terdapat informasi atau dokumen elektronik yang melanggar kesusilaan.

Dari peraturan perundang-undangan yang telah dijelaskan diatas. Maka terdapat lebih dari satu peraturan perundang-undangan yang merupakan peraturan khusus (les spesialis) yang dapat digunakan terhadap pelaku transaksi jualbeli pornografi di media internet. Dari peraturan perundang-undangan yang bersifat khusus tersebut maka yang menjadi pertanyaan adalah peraturan mana yang diberlakukan untuk pelaku transaksi pornografi di media intrenet

Asas lex specialis sistematis atau kekhususan yang sistematis merupakan asas yang dapat digunakan untuk menentukan Undang-Undang Khusus mana yang diberlakukan. Asas ini merupakan derivat atau turunan dari asas lex specialis derogat legi generalis. ${ }^{25}$ Terdapat tiga parameter suatu undang-undang dikualifikasikan sebagai lex specialis sistematis. ${ }^{26}$ Pertama, ketentuan umum materiil yang ada disimpangi dalam ketentuan pidana materiil undang-undang tersebut. Kedua, hukum pidana formil dalam undang-undang tersebut juga menyimpang dari ketentuan acara pidana pada umumnya. Ketiga, adresat atau subjek hukum dalam undang-undang tersebut bersifat khusus.

Terhadap pelaku tindak pidana transaksi pornografi jika menggunakan Undang-Undang PERS maka perbuatan yang dilarang dalam pasal 13 UndangUndang PERS adalah pemuatan iklan yang melanggar kesusilaan. Disini iklan adalah

${ }^{25}$ Edward Omar Sharif Hiariej, 'Asas Lex Specialis Systematis Dan Hukum Pidana Pajak' (2021) 21 Jurnal Penelitian Hukum De Jure.[5].

${ }^{26}$ Eddy O.S Hiariej, 'Lex Specialis Dalam Hukum Pidana'(KOMPAS, 2018), <https:// www-beta.kompas.id/baca/opini/2018/06/12/lex-specialis-dalam-hukum-pidana/>,dikunjungi pada 5 April 2021 
bersifat satu arah yang dimana perusahaan PERS hanya mempublikasikan saja tanpa adanya hubungan timbal balik dari adanya iklan itu. Padahal dalam transaksi pornografi perlu adanya pihak lain yang menyepakati transaksi tersebut karena jika hanya ada penawaran tanpa ada peminat yang sepakat terhadap penawaran tersebut maka transaksi pornografi tidak dapat terjadi.

Jadi Undang-Undang PERS dapat ditegakkan jika terkait penyebarluasan pornografi, tetapi jika dalam transaksi pornografi maka Undang-Undang PERS tidak dapat diterapkan karena hal yang dilarang dalam Undang-Undang PERS adalah iklan, sedangkan iklan adalah publikasi yang tidak ada timbal balik kepada perusahaan PERS sehingga iklan tidak dapat dimasukan dalam konsep transaksi.

Jika milihat Undang-Undang ITE, maka secara hukum pidana formil UndangUndang ITE memiliki penyimpangan seperti diakuinya alat bukti elektronik, tetapi ketentuan hukum pidana materiil dalam Undang-Undang ITE tidak menyimpangi dari ketentuan Hukum pidana umum yaitu KUHP, hal ini karena dalam UndangUndang ITE pornografi dimasukan ke dalam konsep yang sama seperti KUHP yaitu kedalam muatan yang melanggar kesusilaan. Sedangkan konsep kesusilaan dalam KUHP tidak hanya terkait seksualitas tetapi juga perbuatan yang melanggar kesusilaan di masyarakat. Jadi Undang-Undang ITE tidak mengatur secara khusus terkait pornografi tetapi menjadi tindak pidana khusus yang dilakukan dengan menggunakan sistem elektronik, jika melihat Undang-Undang Pornografi maka secara hukum materill telah menyimpang dari KUHP karena pornografi diatur secara spesifik. Dalam Undang-Undang pornografi juga tidak mengatur secara khusus media yang digunakan terkait transaksi pornografi sehingga bagaimanapun caranya pornografi tersebut ditransaksikan maka Undang-Undang pornografi dapat diterapkan. Dengan demikian Undang-Undang pornografi adalah lex specialis sistematis untuk penegakan hukum terhadap pelaku transaksi jualbeli pornografi di media internet.

Jadi Undang-Undang ITE dapat digunakan sebagai dasar dalam menentukan tindak pidana terkait transaksi pornografi di Internet jika bentuk dari pornografi tersebut adalah informasi atau dokumen elektronik dan pendistribusian atau 
pentransmisian dan/atau membuat dapat diaksesnya informasi atau dokumen elektronik tersebut melalui Sistem Elektronik. Jika tidak dalam bentuk informasi atau dokumen elektronik dan tidak melalui Sistem Elektronik maka UndangUndang pornografi yang digunakan dalam transaksi pornografi.

\section{Kesimpulan}

Tindak pidana terkait menyebarluaskan pornografi di media internet yang disertai dengan transaksi jualbeli di dalamnya. Peraturan perundang-undangan yang dapat diterapkan adalah ketentuan Pasal 4 ayat (1) jo. Pasal 29 Undang-Undang Nomor 44 tahun 2008 Tentang Pornografi, dan ketentuan pasal 27 ayat (1) jo pasal 45 ayat (1) Undang-Undang Nomor 11 tahun 2008 jo Undang-Undang Nomor 19 tahun 2016 tentang Informasi dan Transaksi Elektronik. Kemudian Pertanggungjawaban pidana pelaku tindak pidana transaksi pornografi di internet penerapan sanksi pidana terhadap pelaku akan sangat terkait dengan pembuktian unsur perbuatan pelaku di depan persidangan. Hal ini dilihat dari bentuk atau kemasan dari pornografi tersebut. syarat dari digunakannya Undang-Undang ITE adalah barang tersebut harus dalam bentuk informasi atau dokumen elektronik dan disebarluaskan melalui sistem elektronik. Jika proses penawaran, kesepakatan, dan perbuatan tindak pidana pornografi lainnya dilakukan di media internet tetapi produk pornografinya tidak dalam bentuk atau kemasan informasi atau dokumen elektronik dan tidak didistribusikan melalui sistem elektonik maka Undang-Undang ITE tidak dapat digunakan.

\section{Daftar Bacaan.}

\section{Buku}

Adami Chazawi dan Ardi Ferdian, Tindak pidana informasi \& transaksi elektonik penyerangan terhadap kepentingan hukum pemanfaatan teknologi informasi dan transaksi elektronik. (Media nusa creative 2015).

Alexander F. K. Sibero, Kitab Suci Web Programming (MediaKom 2011).

Didik Endro P., Hukum Pidana Untaian Pemikiran (Airlangga University Press 2019). 
2362 Ghozi Naufal: Pertanggungjawaban Pidana Pelaku...

Neng Djubaedah. Pornogafi dan Pornoaksi Ditinjau dari Hukum lslam (Prenada Media 2003).

Peter Mahmud, Pengantar Ilmu Hukum (kencana 2008).

R. Soeroso. Pengantar Ilmu Hukum (Sinar Grafika 2011).

Simanjuntak, Hukum PerdataIIndonesia (kencana 2015).

Soesilo, KUHP Serfa Komentar komentamya Lengkap Pasal demi Pasal (Politei 1995).

S.R. Sianturi. Asas-Asas Hukum Pidana di Indonesia dan Penerapannya (Alumni Ahaem-Petehaem 1996).

Tjipta Lesmana, Pornoqrafi Dalam Media Massa (Puspa Swara 1994).

\section{Jurnal}

Edward Omar Sharif Hiariej, 'Asas Lex Specialis Systematis Dan Hukum Pidana Pajak’ (2021) 21 Jurnal Penelitian Hukum De Jure.

Kassandra Madya, 'Pertanggungjawaban Pidana Terhadap Pelaku Kejahatan Prostitusi Anak Melalui Transaksi Elektronik Berdasarkan Undang-Undang Nomor 19 Tahun 2016 Tentang Informasi Dan Transaksi Elektronik' (2019) 1 Jurnal of Law.

Mutia Rahma Wardani dan Joko Priyono, 'Perlindungan Konsumen Dalam Transaksi Elektronik Melalui Instagram' (2020) 13 NOTARIUS.

\section{Laman}

Eddy O.S Hiariej, 'Lex Specialis Dalam Hukum Pidana'(KOMPAS,2018)<https:// www-beta.kompas.id/baca/opini/2018/06/12/lex-specialis-dalam-hukumpidana/> dikunjungi pada 5 April 2021.

\section{Peraturan Perundang-undangan}

Undang Republik Indonesia Nomor 1 Tahun 1946 Tentang Peraturan Hukum Pidana Undang jo Undang-Undang nomor 73 tahun 1958 Tentang Menyatakan Berlakunya Undang-Undang Nomor 1 Tahun 1946 Republik Indonesia Tentang Peraturan Hukum Pidana Untuk Seluruh Wilayah Republik Indonesia, dan Mengubah Kitab Undang-Undang Hukum Pidana.

Undang-Undang Republik Indonesia Nomor 44 tahun 2008 Tentang Pornografi 
(Lembaran Negara Republik Indonesia Tahun 2008 Nomor 181).

Undang-Undang Nomor 11 Tahun 2008 Tentang Informasi Dan Transaksi Elektronik (Lembaran Negara Republik Indonesia Tahun 2008 Nomor 58).

Peraturan Pemerintah Nomor 82 Tahun 2012 tentang Penyelenggaraan Sistem dan Transaksi Elektronik (Lembaran Negara Republik Indonesia Tahun 2012 Nomor 189).

Peraturan Pemerintah Republik Indonesia Nomor 5 Tahun 2014 Tentang Syarat Dan Tata Cara Perizinan Pembuatan, Penyebarluasan, Dan Penggunaan Produk Pornografi (Lembaran Negara Republik Indonesia Tahun 2014 Nomor 17). 
Ghozi Naufal: Pertanggungjawaban Pidana Pelaku...

--halaman ini sengaja dibiarkan kosong-- 